\title{
Surgical resection for pulmonary recurrence of esophageal cancer after curative esophagectomy
}

\author{
Masaru Morita1, Manabu Yamamoto', Yuichiro Nakashima1, Keiichi Shiokawa1, Yuki Shin', Yoshiaki \\ Fujimoto ${ }^{1}$, Tomonori Nakanoko ${ }^{1}$, Hideo Uehara', Masahiko Sugiyama ${ }^{1}$, Mitsuhiko Ota ${ }^{1}$, Yohei Mano ${ }^{2}$, Keishi \\ Sugimachi' ${ }^{2}$, Tatsuro Okamoto ${ }^{3}$, Yasushi Toh ${ }^{1}$ \\ 'Department of Gastroenterological Surgery, National Hospital Organization Kyushu Cancer Center, Fukuoka 811-1395, Japan. \\ ${ }^{2}$ Department of Hepatobiliary-Pancreatic Surgery, National Hospital Organization Kyushu Cancer Center, Fukuoka 811-1395, \\ Japan. \\ ${ }^{3}$ Department of Thoracic Oncology, National Hospital Organization Kyushu Cancer Center, Fukuoka 811-1395, Japan.
}

Correspondence to: Dr. Masaru Morita, Department of Gastroenterological Surgery, National Hospital Organization Kyushu Cancer Center, 3-1-1 Notame, Minami-ku, Fukuoka 811-1395, Japan. E-mail: morita.masaru.uv@ mail.hosp.go.jp

How to cite this article: Morita M, Yamamoto M, Nakashima Y, Shiokawa K, Shin Y, Fujimoto Y, Nakanoko T, Uehara H, Sugiyama M, Ota M, Mano Y, Sugimachi K, Okamoto T, Toh Y. Surgical resection for pulmonary recurrence of esophageal cancer after curative esophagectomy. J Cancer Metastasis Treat 2021;7:30. https://dx.doi.org/10.20517/2394-4722.2021.93

Received: 7 Apr 2021 First Decision: 6 May 2021 Revised: 7 May 2021 Accepted: 19 May 2021 Available online: 6 Jun 2021

Academic Editor: Lucio Miele Copy Editor: Yue-Yue Zhang Production Editor: Yue-Yue Zhang

\begin{abstract}
Aim: To clarify the significance of surgical resection for pulmonary recurrence after curative esophagectomy for esophageal cancer.
\end{abstract}

Methods: Clinical details, such as the recurrence site, timing, and contents of therapies for recurrence, and the prognosis, were examined in 14 patients who underwent surgical resection for pulmonary recurrence that developed after curative esophagectomy.

Results: The median disease-free interval after esophagectomy was 17.2 months. Two patients underwent pulmonary resection two times, and in one patient, three times. All pulmonary resections were performed when other extra-pulmonary recurrences had been controlled, and RO resection was achieved. Chemotherapy and/or radiotherapy were additionally performed for pulmonary metastasis in 13 patients. The median survival time after initial pulmonary resection was 45.5 months, and the 1-, 3-, and 5-year overall survival rates were 93\%, 68\%, and $43 \%$, respectively. The 5 -year overall survival rate after initial pulmonary resection was $13 \%$ in patients with Stage III or IV esophageal cancer and $100 \%$ in those with Stage I or II disease $(P=0.010)$. The rate was $56 \%$ in patients with tumors $<20 \mathrm{~mm}$ in size, while all 5 patients with lesions $\geq 20 \mathrm{~mm}$ in size died within 3 years $(P=0.005)$. 
Conclusion: Surgical resection along with systemic therapy is a promising treatment strategy for pulmonary recurrence after curative esophagectomy when it is solitary and localized. Clinical factors, such as the esophageal cancer stage and the size of the pulmonary metastasis, are useful for deciding on the surgical indication.

Keywords: Esophageal cancer, pulmonary metastasis, recurrence, surgical resection

\section{INTRODUCTION}

Esophagectomy with radical lymph node dissection is the gold-standard for esophageal cancer; however, it is highly aggressive, and until recently, it was associated with a dismal post-treatment prognosis. Recently, the prognosis following curative esophagectomy has been gradually improving due to multiple factors, such as advancements in diagnostic techniques, improvements in operative methods and perioperative management, and the establishment of adjuvant treatments ${ }^{[1]}$.

However, about half of all patients still develop recurrence even after undergoing curative esophagectomy ${ }^{[2]}$. Most recurrence develops early after esophagectomy, with about $85 \%$ of cases recurring within 2 years, and lymphatic recurrence is the most common recurrence pattern ${ }^{[3-5]}$. Treatment for recurrent disease is generally difficult. In addition to systemic chemotherapy, local treatments, such as radiotherapy, and surgical treatment have been indicated for isolated lymph node recurrence, and the effectiveness of such approaches has been reported ${ }^{[5,6]}$.

Hematogenic recurrence, for which the lung and liver are the most frequent recurrence sites, generally shows multiple and/or multi-organ recurrence. Therefore, the prognosis of this type of recurrence is dismal, with systemic chemotherapy mainly performed ${ }^{[3,5]}$. While the incidence is not high, hematogenic recurrence after curative esophagectomy shows "oligometastases", namely a type of recurrence associated with a limited number of tumors that are restricted to one particular region. Recently, the effectiveness of surgical resection for such types of recurrence has been reported; however, the clinical significance of lung recurrence, which is the most frequent hematogenic recurrence site, has never been established ${ }^{[7,8]}$.

To clarify the significance of surgical resection for pulmonary recurrence after curative esophagectomy, we examined the clinical details of 14 cases and reviewed available previously reported studies.

\section{METHODS}

Three hundred and sixty-six patients with esophageal cancer underwent curative esophagectomy (Ro resection) between 2003 and 2018 at the National Hospital Organization Kyushu Cancer Center. Among these patients, recurrence was recognized in 145 patients, and the details of recurrence were available for 138 patients. The subjects of this study were the 14 patients who underwent surgical resection for pulmonary recurrence; the clinical details of these patients, such as the recurrence site, timing of recurrence, contents of therapies for recurrence, and the prognosis, were examined.

This study was approved by the Institutional Board in National Hospital Organization Kyushu Cancer Center (No. 2020-93) and was conducted in accordance with the 1964 Declaration of Helsinki. Written informed consent was collected from each patient.

All patients underwent subtotal esophagectomy with a cervico-right thoraco-abdominal approach along with radical lymphadenectomy and reconstruction with a gastric tube. Six and one patients received neoadjuvant chemotherapy and chemoradiotherapy, followed by esophagectomy, respectively, while 
adjuvant chemotherapy for esophageal cancer was indicated for four patients. In two patients, definitive chemoradiotherapy was initially performed for esophageal cancer, and salvage esophagectomy was indicated for recurrent and remnant esophageal cancer.

Screening for recurrence after esophagectomy was regularly and intensively performed with radiological imaging, physical exam, and tumor markers. Cervical, chest, and abdominal computed tomography (CT) and abdominal ultrasonography were performed every four months for the first two years and every six months thereafter, until at least five years after esophagectomy ${ }^{\left[{ }^{[\rho]}\right.}$. Clinicopathological factors were examined according to the guidelines of the Japan Esophageal Society ${ }^{[10]}$, and the UICC TNM Classification of Malignant Tumours 8 th edition ${ }^{[1]}$ was adopted.

The clinical diagnosis of metastasis was made mainly according to the findings of chest CT as well as fluorodeoxyglucose-positron emission tomography $\left({ }^{18} \mathrm{~F}-\mathrm{FDG}-\mathrm{PET}\right)$ images in some cases. In our institute, the differential diagnosis as well as therapeutic strategies for pulmonary tumors developing after esophagectomy are carefully discussed among members of the interdisciplinary tumor board, which comprises of gastrointestinal surgeons, thoracic surgeons, diagnostic radiologists, medical oncologists, and radiation oncologists. Systemic chemotherapy is principally indicated for hematogenic recurrence, such as lung metastasis, and radiotherapy is sometimes considered for local control. Strict operative indications are adopted only for solitary lung metastasis in principle, and any other recurrence is completely controlled. Partial resection (e.g., wedge resection) of the lung is performed for peripheral-type pulmonary metastasis, while minimum-extent pulmonary resection is considered for central-type metastasis. The diagnosis is confirmed by comparing the histological findings of the resected pulmonary tumor with those of the primary esophageal cancer. The size of the pulmonary metastases was measured using horizontal slice CT images, and the maximum diameter was adopted for this study.

The survival curves were plotted according to the Kaplan-Meier method, and any differences between two curves were analyzed using the log-rank test. Differences were considered to be significant if the $P$-value were less than 0.05. Data were analyzed using the StatView software package (Abacus Concepts, Inc., Berkeley, CA, USA).

\section{RESULTS}

The mean age of the patients was 60.5 years old at the time of esophagectomy, and the male-to-female ratio was 13:1. Mid-thoracic esophagus was the most frequent location of primary esophageal cancer, and the TNM stages were I, II, III, and IV, in 4, 2, 6, and 2 patients, respectively. Twelve patients were pathologically diagnosed with squamous cell carcinoma, and of the remaining 2, 1 was diagnosed with basaloid carcinoma and the other with adenosquamous cell carcinoma. The initial recurrence site was the lung in 12 patients, the neck in 1 patient, and the upper mediastinum in 1 patient. The median disease-free interval (DFI) after esophagectomy (interval between esophagectomy and detection of initial recurrence) was 17.2 months. Two patients underwent pulmonary resection 2 times, and one patient underwent it 3 times; therefore, pulmonary resection was performed a total of 17 times in these 14 patients [Table 1 ].

Table 2 shows the patients' details. The patient who had cervical lymph node recurrence (Case \#12) underwent radical neck dissection, followed by chemoradiotherapy. As a result, the lymph node recurrence was controlled, and pulmonary resection was performed for subsequent lung metastasis. In the patient who had upper mediastinum lymph node recurrence (Case \#14), the metastasized nodes had completely disappeared after chemoradiotherapy, and chemotherapy followed by pulmonary resection were performed later. Including these two cases, all pulmonary resections were performed once other extra-pulmonary 
Table 1. Clinical factors of 14 patients who underwent pulmonary resection for pulmonary recurrence after curative esophagectomy

\begin{tabular}{lll}
\hline Factors & & $\begin{array}{l}\text { No. of patients (or } \\
\text { operations) } \\
\text { Values }\end{array}$ \\
\hline Age (years) & Mean (range) & $60.5(50-75)$ \\
Gender & Male/female & $13 / 1$ \\
Location of esophageal cancer & Upper/mid-/lower thoracic esophagus & $3 / 7 / 4$ \\
Depth of invasion & T1b/T2/T3/T4a & $4 / 2 / 6 / 2$ \\
Node metastasis & NO/N1/N2/N3 & $3 / 8 / 3$ \\
Organ metastasis & MO/M1 & $14 / 0$ \\
UICC Stage & I/II/II/IV & $3 / 2 / 7 / 2$ \\
Histology of esophageal cancer & Squamous cell carcinoma/basaloid carcinoma/adenosquamous cell & $12 / 1 / 1$ \\
& carcinoma & $17.2(2.8-42.5)$ \\
DFl after esophagectomy (months) & Median (range) & $12 / 2$ \\
Location of initial recurrence & Lung/lymph node & $18(6-35)$ \\
Diameter of initial pulmonary & Mean (range) & $11 / 2 / 1$ \\
recurrence (mm) & $1 / 2 / 3$ & $10 / 2 / 3 / 3$ \\
Number of pulmonary resections & Wedge resection/segmentectomy/lobectomy/combined resection of \\
Method of pulmonary resection & other organs & \\
\hline
\end{tabular}

DFI: Disease-free interval after esophagectomy (interval between esophagectomy and initial recurrence).

recurrences had been controlled. Partial resection of bilateral solitary metastatic tumors was simultaneously performed at the time of initial metastasectomy for one patient (Case \#3). However, all other resected metastases were solitary at the time of their resection. All resections were complete (Ro resection). Chemoand/or radiotherapies were additionally performed for pulmonary metastasis before or after surgical resections in 13 patients. In Case \#13, partial hepatectomy was performed for liver metastasis that developed 18 months after pulmonary resection [Table 2].

Among 14 patients, 8 died due to esophageal cancer, and 1 died due to small-cell carcinoma of the lung; the remaining five were still alive without regrowth. The median observation periods and ranges were 74.5 (28.2-128.1) months after esophagectomy, 49.2 (12.1-107.2) months after initial recurrence, and 41.1 (12.0106.4) months after initial pulmonary resection. The 1-, 3-, and 5-year overall survival rates after esophagectomy were $100 \%, 78 \%$, and $70 \%$, respectively, and those after initial recurrence were $100 \%, 70 \%$, and $45 \%$, respectively; the median survival time after initial recurrence was 49.5 months. Regarding the prognosis after the initial pulmonary resection, the 1-, 3-, and 5-year overall survival rates were $93 \%, 68 \%$, and $43 \%$, respectively, and the median survival time was 45.5 months [Figure 1].

To clarify the prognostic factors, we evaluated the prognoses after initial pulmonary resection according to the clinical stage of esophageal cancer and DFI after esophagectomy as well as the size of the pulmonary metastasis and extra-pulmonary lesions at the time of initial resection. Statistically significant differences were recognized in the clinical stage and size of pulmonary metastasis. The 5-year overall survival rate after initial pulmonary resection was $13 \%$ in patients with Stage III or IV esophageal cancer and $100 \%$ in those with Stage I or II disease $(P=0.010)$. Furthermore, 4 patients were still alive 5 years, and 1 had been alive for 28.5 months after initial pulmonary resection at the time of the observation. Concerning the size of the metastatic lung tumor, the 5 -year survival rate was $56 \%$ in patients with tumors $<20 \mathrm{~mm}$ in size, while all 5 patients with tumors $\geq 20 \mathrm{~mm}$ in size died within 3 years after pulmonary resection $(P=0.005)$. The tumor size of the initial pulmonary metastasis was also significantly associated with the prognosis when focusing on patients with Stage III/IV esophageal cancer $(P=0.040$, Table 3). 
Table 2. Details of the 14 patients who underwent pulmonary resection for pulmonary recurrence after curative esophagectomy

\begin{tabular}{|c|c|c|c|c|c|c|c|c|c|c|c|c|c|}
\hline \multirow[b]{2}{*}{ Pt } & \multirow{2}{*}{\multicolumn{2}{|c|}{$\begin{array}{l}\text { Age } \\
\text { Sex }\end{array}$}} & \multirow[b]{2}{*}{$\begin{array}{l}\text { TNM, Stage } \\
\text { (UICC 8th } \\
\text { ed.) }\end{array}$} & \multicolumn{2}{|c|}{ Initial recurrence } & \multicolumn{5}{|c|}{ Pulmonary resection } & \multirow[b]{2}{*}{ Prognosis } & \multirow[b]{2}{*}{$\begin{array}{l}\text { Time after } \\
\text { initial } \\
\text { recurrence } \\
\text { (months) }\end{array}$} & \multirow[b]{2}{*}{$\begin{array}{l}\text { Time after initial } \\
\text { pulmonary } \\
\text { resection } \\
\text { (months) }\end{array}$} \\
\hline & & & & Location & $\begin{array}{l}\text { DFI } \\
\text { (months) }\end{array}$ & $\begin{array}{l}\text { Number of } \\
\text { resections }\end{array}$ & $\begin{array}{l}\text { Time after } \\
\text { esophagectomy } \\
\text { (months) }\end{array}$ & $\begin{array}{l}\text { Diameter of } \\
\text { initial lung } \\
\text { metastasis } \\
(\mathrm{mm})\end{array}$ & $\begin{array}{l}\text { Preoperative } \\
\text { therapy }\end{array}$ & $\begin{array}{l}\text { Postoperative } \\
\text { therapy }\end{array}$ & & & \\
\hline 1 & 55 & M & $\begin{array}{l}\text { T4aNO MO } \\
\text { Stage IVA }\end{array}$ & lung & 3.8 & 1 & 6.2 & 15 & - & CRT & Cancer death & 31.3 & 29.0 \\
\hline 2 & 51 & M & $\begin{array}{l}\text { T3N1MO } \\
\text { Stage III }\end{array}$ & lung & 5.9 & 1 & 15.2 & 35 & C & - & Alive & 27.3 & 18.0 \\
\hline 3 & 63 & M & $\begin{array}{l}\text { T1bN1M0 } \\
\text { Stage I }\end{array}$ & lung & 14.2 & $1^{\star}$ & 14.9 & 6 & - & C & Alive & 107.2 & 106.4 \\
\hline 4 & 49 & M & $\begin{array}{l}\text { T3N2MO } \\
\text { Stage III }\end{array}$ & lung & 14.2 & 1 & 14.9 & 20 & - & C & Cancer death & 35.9 & 35.2 \\
\hline 5 & 61 & M & $\begin{array}{l}\text { T2N1M0 } \\
\text { Stage II }\end{array}$ & lung & 15.7 & 1 & 21.0 & 9 & - & - & Alive & 66.1 & 60.8 \\
\hline 6 & 64 & M & $\begin{array}{l}\text { T3N1MO } \\
\text { Stage III }\end{array}$ & lung & 16.0 & 1 & 20.9 & 16 & - & R & Cancer death & 49.5 & 44.7 \\
\hline 7 & 75 & M & $\begin{array}{l}\text { T3N1MO } \\
\text { Stage III }\end{array}$ & lung & 16.1 & 2 & 16.2 & 26 & C (2nd ope.) & C (1st ope.) & Cancer death & 12.1 & 12.0 \\
\hline 8 & 58 & M & $\begin{array}{l}\text { T1bN1M0 } \\
\text { Stage I }\end{array}$ & lung & 18.4 & 1 & 38.7 & 21 & $\mathrm{R}$ & - & Alive & 48.8 & 28.5 \\
\hline 9 & 67 & M & $\begin{array}{l}\text { T4aNO MO } \\
\text { Stage IVA }\end{array}$ & lung & 18.6 & 1 & 10.9 & 31 & - & $\mathrm{R}$ & Cancer death & 16.0 & 23.7 \\
\hline 10 & 65 & M & $\begin{array}{l}\text { T2NO MO } \\
\text { Stage II }\end{array}$ & lung & 20.5 & 3 & 21.5 & 12 & $\begin{array}{l}\text { C (1st, 2nd and } \\
\text { 3rd ope.) }\end{array}$ & $\begin{array}{l}\text { C (1st and 2nd } \\
\text { ope.) }\end{array}$ & Cancer death & 99.2 & 98.3 \\
\hline 11 & 50 & M & $\begin{array}{l}\text { T1bN2MO } \\
\text { Stage III }\end{array}$ & lung & 22.1 & 2 & 22.9 & 18 & - & C (2nd ope.) & $\begin{array}{l}\text { Death due to } \\
\text { small cell ca. of } \\
\text { the lung }\end{array}$ & 64.2 & 63.5 \\
\hline 12 & 55 & $\mathrm{~F}$ & $\begin{array}{l}\text { T3N2MO } \\
\text { Stage III }\end{array}$ & $\begin{array}{l}\text { lymph } \\
\text { node }\end{array}$ & 24.3 & 1 & 44.6 & 11 & $\begin{array}{l}\text { Cervical node } \\
\text { dissection, CRT }\end{array}$ & C & Cancer death & 57.7 & 37.5 \\
\hline 13 & 68 & M & $\begin{array}{l}\text { T3N1MO } \\
\text { Stage III }\end{array}$ & lung & 37.0 & 1 & 38.0 & 14 & - & C, Hepatectomy & Cancer death & 46.5 & 45.5 \\
\hline 14 & 66 & M & $\begin{array}{l}\text { T1bN1MO } \\
\text { Stage I }\end{array}$ & $\begin{array}{l}\text { lymph } \\
\text { node }\end{array}$ & 42.5 & 1 & 77.0 & 10 & $\begin{array}{l}\text { CRT to } \\
\text { mediastinum } \\
\rightarrow C\end{array}$ & - & Alive & 85.6 & 51.1 \\
\hline
\end{tabular}

*Partial resection of the lung for bilateral solitary metastases was simultaneously performed in Case \#3. DFI: Disease-free interval after esophagectomy (interval between esophagectomy and initial recurrence) CRT: chemoradiotherapy; C: chemotherapy. 


\section{DISCUSSION}

Among gastrointestinal cancer cases, surgical resection for hematogenic recurrence after curative colectomy for colorectal cancer is frequently indicated, and its clinical significance is well established, especially when Ro resection can be achieved ${ }^{[12]}$. Regarding esophageal cancer, pulmonary recurrence after esophagectomy frequently shows multiple recurrence in the lung and is also frequently associated with recurrence in other organs as well as lymph node recurrence. Therefore, it tends to be considered a "systemic disease", and systemic chemotherapy is held as the main treatment of this type of recurrence. Additional radiotherapy is sometimes indicated for either local control or symptom palliation. We agree with this treatment strategy, and based on this concept, surgical resection is not usually indicated. However, Shimada et al. ${ }^{[13]}$ and Kunisaki et al. ${ }^{[14]}$ have reported the clinical results of surgical resection for "oligometastases", which indicate a small number of localized metastases restricted to a single region and/or a single organ.

The prognosis after esophagectomy has been markedly improved due to advances in operative procedures as well as the perioperative management and adjuvant and/or neoadjuvant treatments. The clinical results of several patients who underwent surgical resection for recurrent lesions after esophagectomy have recently been reported from high-volume centers in Japan and Western countries. Therefore, even in cases of hematologic recurrence, surgical resection may be an effective treatment option for patients with "oligometastases" restricted to a single region and/or a single organ ${ }^{[4,7,15]}$. We previously examined 100 cases of recurrence that developed after curative esophagectomy in other institutions and reported that the prognoses of the 14 patients who underwent surgical resection for any type of recurrence had significantly better outcomes compared to other patients who did not undergo surgical resection, with respective DFIs of 92.2 months and 12.2 months, respectively. Among those patients, four underwent pulmonary resection. We concluded that surgical resection for the recurrent site may be a viable treatment option when the recurrent lesion is solitary or localized and emphasized the importance of combined chemotherapy and/or radiotherapy ${ }^{[16]}$. In the present study, we evaluated the clinical significance of surgical resection while paying close attention to the incidence of pulmonary recurrence. As a result, fairly favorable results were confirmed, with a 5-year OS of $43 \%$ and a median survival time of 45.5 months after pulmonary resection.

According to the PubMed database, most references describing the clinical results of surgical resection for lung recurrence thus far have originated from Japan, and the clinical results are summarized in Table $4^{[16-26]}$. Esophageal cancer frequently shows recurrence within two years after curative treatment ${ }^{[3-5]}$. The previous findings reflect these characteristics, and most DFIs, including that in the current study, have ranged from 12 to 24 months. The prognosis after pulmonary resection is fairly favorable, even for cases of recurrent esophageal cancer, and the 5-year overall survival rates have ranged from roughly $30 \%$ to $45 \%$, except for that in the study by Kozu et al. ${ }^{[23]}$. The 5 -year survival rate of $43 \%$ in our current study is reasonable and comparable to those of Ichikawa et al. ${ }^{[20]}$ and Kanamori et al. ${ }^{[24]}$. In cases with pulmonary recurrence, we have strictly determined surgical indications: namely, the metastatic lesion is solitary and localized, and any other recurrence is completely controlled. Indeed, most pulmonary metastasis presented as a "solitary" lesion at the time of metastasectomy in the current study, except for one case with bilateral solitary metastases (Case \#3), who survived for 107 months after metastasectomy without further recurrence. In addition, we would like to emphasize the fact that systemic therapy is the gold standard for lung metastasis, since lung metastasis reflects "systemic disease", even when it is solitary. We therefore principally perform combined systemic chemotherapy for lung metastasis. These results strongly support the notion that multimodal therapies, including not only systemic chemotherapy but also local therapies, such as radiation and pulmonary resection with strict surgical indications, might be important for treating oligometastases after esophagectomy, as described in our previous report ${ }^{[16]}$ and other reports ${ }^{[22,24]}$. 
Table 3. The overall survival after initial pulmonary resection according to prognostic factors

\begin{tabular}{|c|c|c|c|c|c|c|}
\hline \multirow{2}{*}{ Factors } & & \multirow{2}{*}{$\mathbf{N}$} & \multicolumn{3}{|c|}{ Overall survival after initial pulmonary resection (\%) } & \multirow{2}{*}{$P$ values } \\
\hline & & & 1 year & 3 years & 5 years & \\
\hline \multirow[t]{2}{*}{ Stage of esophageal cancer } & I, II & 5 & 100 & 100 & 100 & 0.010 \\
\hline & III, IV & 9 & 89 & 51 & 13 & \\
\hline \multirow[t]{2}{*}{$\mathrm{DFI}$} & $<18$ months & 7 & 86 & 51 & 34 & 0.719 \\
\hline & $\geqq 18$ months & 7 & 100 & 86 & 51 & \\
\hline \multirow[t]{2}{*}{ Diameter of initial lung metastasis } & $<20 \mathrm{~mm}$ & 9 & 100 & 89 & 56 & 0.005 \\
\hline & $\geqq 20 \mathrm{~mm}$ & 5 & 80 & 0 & 0 & \\
\hline \multirow[t]{2}{*}{ Extra-pulmonary lesions at initial recurrence } & present & 2 & 100 & 50 & NA & 0.775 \\
\hline & absent & 12 & 92 & 62 & 41 & \\
\hline \multicolumn{7}{|l|}{ Stage III/IV esophageal cancer } \\
\hline \multirow[t]{2}{*}{ Diameter of initial lung metastasis } & $<20 \mathrm{~mm}$ & 5 & 100 & 80 & 20 & 0.040 \\
\hline & $\geqq 20 \mathrm{~mm}$ & 4 & 75 & 0 & 0 & \\
\hline
\end{tabular}

DFI: Disease-free interval; NA: not available.

To clarify the prognostic factors after surgical resection for pulmonary metastasis, we reviewed the references [Table 4] and evaluated the respective factors in the current study. Regarding primary esophageal cancer, both nodal involvement and poorly differentiated squamous cell carcinoma are reported to be unfavorable prognostic factors after resection of pulmonary recurrence, but a short DFI is also a significant prognostic factor ${ }^{[1722,24]}$. Furthermore, multiple large metastases as well as the presence of extra-pulmonary metastases are reported to be unfavorable prognostic factors after resection ${ }^{[20,22-24]}$. In the report examining the prognosis of either lung or liver metastasis, surgical resection for metastasis as well as the size of the metastasis are reported to be prognostic factors ${ }^{[21]}$. In the current study, both stage III or IV esophageal cancer and pulmonary metastasis $\geq 20 \mathrm{~mm}$ in size were found to be prognostic factors after pulmonary resection, findings that are consistent with those of other reports. Furthermore, we examined the difference in the prognosis by metastatic tumor size among patients with stage III/IV esophageal cancer. We found that a larger metastatic lesion was an unfavorable prognostic factor among patients with initially advanced esophageal cancer. These prognostic factors are useful for determining treatment strategies for pulmonary recurrence after curative esophagectomy. When debating the surgical indication, it is important to not only consider primary tumor factors, such as the initial tumor stage and histological differentiation of esophageal cancer, but also to independently take into account markers reflecting biological behavior, such as the DFI, and factors reflecting the metastatic burden (tumor size and number).

Several limitations associated with the present study warrant mention. First, the number of patients who underwent metastasectomy was only 14, and these patients received various initial multimodal treatments and subsequent treatment other than pulmonary resection. To compensate for this limitation, we reviewed other studies and found that results of these studies supported our current findings. Second, most of our cases were histologically squamous cell carcinoma, and no cases of adenocarcinoma were included. Furthermore, all studies describing pulmonary resection originated from Japan and included mainly squamous cell carcinoma. Third, only "solitary" pulmonary metastasis was indicated for surgery in our study, a restriction that is too strict to allow for the evaluation of the clinical significance of resection for "oligometastases".

In conclusion, surgical resection in addition to chemotherapy and/or radiotherapy for pulmonary recurrence after curative esophagectomy is a promising treatment strategy with the potential to result in a long-term survival when the recurrence is solitary and localized. Clinical factors, such as the stage of 
Table 4. Study regarding surgical resection for pulmonary recurrence after curative treatment of esophageal cancer

\begin{tabular}{|c|c|c|c|c|c|c|c|c|c|c|}
\hline \multirow{3}{*}{$\begin{array}{l}\text { Author } \\
\text { Year }\end{array}$} & \multirow{3}{*}{$\mathbf{N}$} & \multirow{3}{*}{ Histology } & \multirow{3}{*}{$\begin{array}{l}\text { Therapy for } \\
\text { esophageal } \\
\text { cancer }\end{array}$} & \multirow{3}{*}{$\begin{array}{l}\text { DFI } \\
\text { (months) } \\
\text { median, } \\
\text { range }\end{array}$} & \multicolumn{5}{|c|}{ Prognosis after pulmonary resection } & \multirow{3}{*}{$\begin{array}{l}\text { PFs, either after } \\
\text { pulmonary } \\
\text { resection or for } \\
\text { lung metastasis } \\
\text { (unfavorable } \\
\text { factors) }\end{array}$} \\
\hline & & & & & \multirow{2}{*}{$\begin{array}{l}\text { Observation } \\
\text { period } \\
\text { median, } \\
\text { range }\end{array}$} & \multirow{2}{*}{$\begin{array}{l}\text { MST } \\
\text { (months) }\end{array}$} & \multicolumn{3}{|c|}{ Survival rate (\%) } & \\
\hline & & & & & & & $\begin{array}{l}1 \\
\text { year }\end{array}$ & $\begin{array}{l}3 \\
\text { years }\end{array}$ & $\begin{array}{l}5 \\
\text { years }\end{array}$ & \\
\hline Shiono et al. ${ }^{[17]}, 2008$ & 49 & $\begin{array}{l}\text { SCC } 48 \\
\text { Adenoca. } 1\end{array}$ & $\begin{array}{l}\text { Ope. } 47 \\
\text { Radiation } 2\end{array}$ & $\begin{array}{l}14 \\
(0-124)\end{array}$ & $\begin{array}{l}18 \\
(0-206)\end{array}$ & 18 & NA & NA & 29.6 & $\begin{array}{l}\text { PFs after pulmonary } \\
\text { resection } \\
\text { DFI (<12 months) }\end{array}$ \\
\hline Chen et al. ${ }^{[18]}, 2008$ & 5 & $\operatorname{scC} 5$ & Ope. 5 & $\begin{array}{l}21 \\
(13-56)\end{array}$ & $\begin{array}{l}24 \\
(11-90) \\
4 \text { pts, alive }\end{array}$ & NA & $(80)$ & $(80)$ & $(80)$ & NA \\
\hline $\begin{array}{l}\text { Takemura et al. }{ }^{[19]} \text {, } \\
2012\end{array}$ & 5 & $\begin{array}{l}\text { SCC } 4 \\
\text { Basaloid } 1\end{array}$ & Ope. 5 & NA & $\begin{array}{l}48 \\
(6-124) \\
4 \text { pts, alive }\end{array}$ & NA & $(100)$ & $(100)$ & $(75)$ & $\begin{array}{l}\text { PFs for lung } \\
\text { metastasis } \\
\text { Number of lung } \\
\text { metastases } \\
\text { (Multiple) } \\
\text { Extrapulmonary } \\
\text { lesions }\end{array}$ \\
\hline Ichikawa et al. ${ }^{[20]}, 2011$ & 24 & $\begin{array}{l}\text { SCC } 21 \\
\text { Adenoca. } 1 \\
\text { CS } 1\end{array}$ & $\begin{array}{l}\text { Ope. } 20 \\
\text { CRT } 3\end{array}$ & $\begin{array}{l}15.5 \\
(3.8-79.1)\end{array}$ & $\begin{array}{l}48.2 \\
(26.1-214.5)\end{array}$ & $\begin{array}{l}28.7 \\
(4.9-214.5)\end{array}$ & 73.9 & 43.5 & 43.5 & $\begin{array}{l}\text { PFs after pulmonary } \\
\text { resection } \\
\text { Extrapulmonary } \\
\text { lesions at initial } \\
\text { recurrence }\end{array}$ \\
\hline Ichida et al. ${ }^{[21]}, 2013$ & 5 & SCC 5 & Ope. 5 & $\begin{array}{l}6 \\
(0-18)\end{array}$ & $\begin{array}{l}48 \\
(10-63)\end{array}$ & $\begin{array}{l}48 \\
(10-63)\end{array}$ & 80 & 60 & 20 & $\begin{array}{l}\text { PFs for lung or liver } \\
\text { metastasis } \\
\text { Surgical resection } \\
\text { (Not performed) } \\
\text { Size of metastasis ( } \geq \\
21 \mathrm{~mm} \text { ) }\end{array}$ \\
\hline $\begin{array}{l}\text { Kobayashi et al. }{ }^{[22]} \text {, } \\
2014\end{array}$ & 23 & $\begin{array}{l}\text { SCC } 22 \\
\text { CS } 1\end{array}$ & $\begin{array}{l}\text { Ope. } 17 \\
\text { CRT } 5 \\
\text { ESD } 1\end{array}$ & $\begin{array}{l}23.8 \\
(0-61)\end{array}$ & $\begin{array}{l}37.4 \\
(1-114)\end{array}$ & $\begin{array}{l}37.4 \\
(1-114)\end{array}$ & 82.6 & 46 & 34.1 & $\begin{array}{l}\text { PFs after pulmonary } \\
\text { resection } \\
\text { Extrapulmonary } \\
\text { lesions at initial } \\
\text { recurrence } \\
\text { Differentiation of } \\
\text { SCC (Poorly) } \\
\text { DFI (<12 months) }\end{array}$ \\
\hline Hiyoshi et al. ${ }^{[16]}, 2015$ & 4 & NA & Ope. 4 & $\begin{array}{l}16.6 \\
(4.6-41.3)\end{array}$ & $\begin{array}{l}25.3 \\
(10.7-42) \\
3 \text { pts, alive }\end{array}$ & NA & $(100)$ & $(67)$ & NA & NA \\
\hline Kozu et al. ${ }^{[23]}, 2015$ & 15 & SCC 15 & Ope. 15 & & & 32 & 93 & 44 & 0 & $\begin{array}{l}\text { PFs after pulmonary } \\
\text { resection } \\
\text { Size of metastasis ( } \geq \\
20 \mathrm{~mm} \text { ) }\end{array}$ \\
\hline $\begin{array}{l}\text { Kanamori et al. }{ }^{[24]}, \\
2017\end{array}$ & 33 & $\begin{array}{l}\text { SCC } 32 \\
\text { Basaloid } 1\end{array}$ & $\begin{array}{l}\text { Ope. } 16 \\
\text { CRT } 14 \\
\text { ESD } 3\end{array}$ & $\begin{array}{l}15 \\
(3-60)\end{array}$ & $\begin{array}{l}17.9 \\
(2-92)\end{array}$ & $\begin{array}{l}17.9 \\
(3-92)\end{array}$ & 79.4 & 47.8 & 43 & $\begin{array}{l}\text { PFs after pulmonary } \\
\text { resection } \\
\text { DFI (<16 months) } \\
\text { Node metastasis at } \\
\text { esophagectomy } \\
\text { (positive) }\end{array}$ \\
\hline Kato et al. ${ }^{[25]}, 2018$ & 6 & $\operatorname{scc} 6$ & $\begin{array}{l}\text { Ope. } 3 \\
\text { CRT } 3\end{array}$ & NA & NA & NA & 100 & 60 & 60 & NA \\
\hline Shimada et al. ${ }^{[26]}, 2019$ & 4 & $\operatorname{sCC} 4$ & Ope. or CRT & NA & NA & 37.3 & 100 & 100 & 0 & NA \\
\hline $\begin{array}{l}\text { Morita et al. } \\
\text { Current study, } 2021\end{array}$ & 14 & $\begin{array}{l}\text { SCC } 12 \\
\text { Basaloid } 1 \\
\text { AdSCC } 1\end{array}$ & Ope. 14 & $\begin{array}{l}17.3 \\
(3.8-42.5)\end{array}$ & $\begin{array}{l}41.1 \\
(12-106.4) \\
5 \text { pts, alive }\end{array}$ & $\begin{array}{l}45.5 \\
(12-106.4)\end{array}$ & 93 & 68 & 43 & $\begin{array}{l}\text { PFs after pulmonary } \\
\text { resection } \\
\text { Stage of esophageal } \\
\text { cancer (Stage III, IV) } \\
\text { Size of metastasis ( } \geq \\
20 \mathrm{~mm} \text { ) }\end{array}$ \\
\hline
\end{tabular}

NA: Not available; SCC: squamous cell carcinoma; CS: carcinosarcoma; AdSCC: adenosquamous cell carcinoma; Ope: operation; CRT: chemoradiotherapy; ESD: endoscopic submucosal resection; DFI: disease-free interval; MST: median survival time; PF: prognostic factor.

esophageal cancer and size of the pulmonary metastasis, may be useful for deciding on the surgical 
A

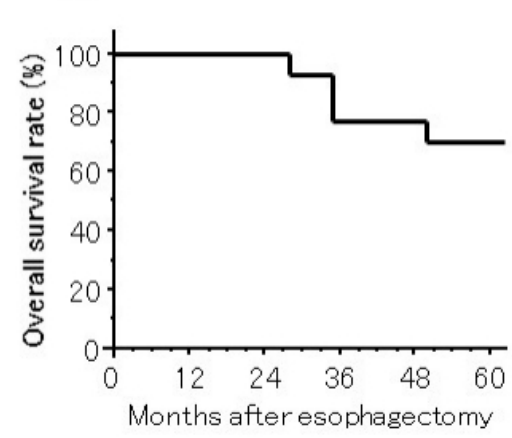

B

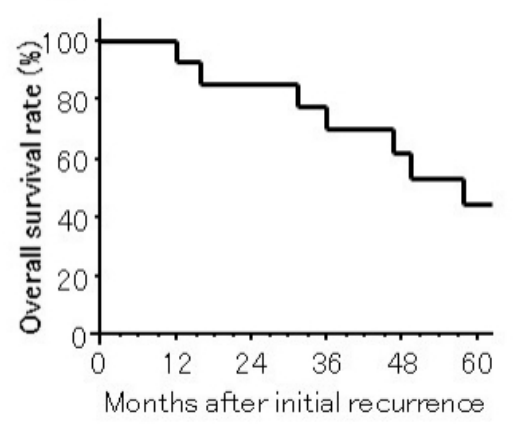

C

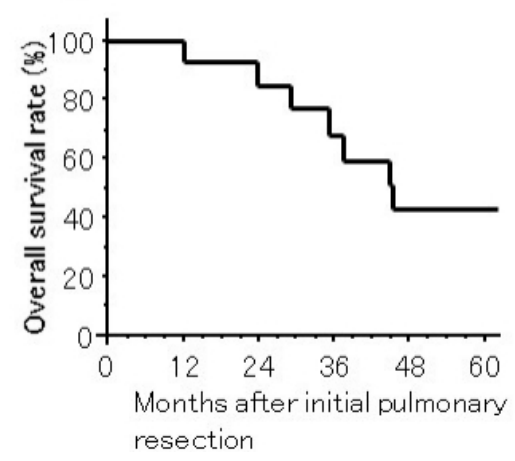

Figure 1. The OS in patients who underwent surgical resection for pulmonary recurrence after curative esophagectomy. (A) The OS after esophagectomy; (B) The OS after detection of initial recurrence; (C) The OS after initial pulmonary resection. OS: Overall survival.

indication.

\section{DECLARATIONS}

\section{Acknowledgements}

We thank Brian Quinn for assisting with the preparation of the manuscript.

\section{Authors' contribution}

Conceptualizing and designing the study, and writing the manuscript: Morita $\mathrm{M}$

Contributing intellectual input, (mainly for esophageal surgery): Yamamoto M, Nakashima Y

Collecting the data: Shiokawa K, Shin Y, Fujimoto Y, Nakanoko T, Uehara H

Performing the data analysis and interpretation: Sugiyama M, Ota M

Providing technical and material support: Mano Y, Sugimachi K

Contributing intellectual input (mainly for thoracic surgery): Okamoto $\mathrm{T}$

Supervising the entire study: Toh Y

\section{Financial support and sponsorship}

This work was supported in part by a Grant-in-Aid from the Ministry of Education, Culture, Sport, Science and Technology of Japan (JSPS KAKENHI Grant number JP21K08766).

\section{Conflicts of interest}

All authors declared that there are no conflicts of interest.

\section{Ethical approval and consent to participate}

This study was approved by the Institutional Board in National Hospital Organization Kyushu Cancer Center (No. 2020-93) and was conducted in accordance with the 1964 Declaration of Helsinki. Written informed consent was collected from each patient.

\section{Consent for publication}

Not applicable.

\section{Copyright}

(c) The Author(s) 2021. 


\section{REFERENCES}

1. Morita M, Yoshida R, Ikeda K, et al. Advances in esophageal cancer surgery in Japan: an analysis of 1000 consecutive patients treated at a single institute. Surgery 2008;143:499-508. DOI PubMed

2. Watanabe M, Tachimori Y, Oyama T, et al. Comprehensive registry of esophageal cancer in Japan, 2013. Esophagus 2021;18:1-24. DOI PubMed PMC

3. Sugiyama M, Morita M, Yoshida R, et al. Patterns and time of recurrence after complete resection of esophageal cancer. Surg Today 2012;42:752-8. DOI PubMed

4. Yamashita K, Watanabe M, Mine S, et al. Patterns and outcomes of recurrent esophageal cancer after curative esophagectomy. World $J$ Surg 2017;41:2337-44. DOI PubMed

5. Hamai Y, Hihara J, Emi M, et al. Treatment outcomes and prognostic factors after recurrence of esophageal squamous cell carcinoma. World J Surg 2018;42:2190-8. DOI PubMed

6. Wang Z, Lin S, Wang F, Liu S. Salvage lymphadenectomy for isolated cervical lymph node recurrence after curative resection of thoracic esophageal squamous cell carcinoma. Ann Transl Med 2019;7:238. DOI PubMed PMC

7. Ohkura Y, Shindoh J, Ueno M, Iizuka T, Udagawa H. Clinicopathologic Characteristics of Oligometastases from Esophageal Cancer and Long-Term Outcomes of Resection. Ann Surg Oncol 2020;27:651-9. DOI PubMed

8. Schizas D, Lazaridis, II, Moris D, et al. The role of surgical treatment in isolated organ recurrence of esophageal cancer-a systematic review of the literature. World J Surg Oncol 2018;16:55. DOI PubMed PMC

9. Toh Y, Oki E, Minami K, Okamura T: Follow-up and recurrence after a curative esophagectomy for patients with esophageal cancer: the first indicators for recurrence and their prognostic values.

Esophagus 2010;7:37-41.

10. Kuwano H, Nishimura Y, Oyama T, et al. Guidelines for Diagnosis and Treatment of Carcinoma of the Esophagus April 2012 edited by the Japan Esophageal Society. Esophagus 2015;12:1-30. DOI PubMed PMC

11. TNM Classification of Malignant Tumours, 8th edition: John Wiley \& Sons, Ltd; 2018. Available from: https://www.uicc.org/sites/mai n/files/atoms/files/TNM_Classification_of_Malignant_\%20Tumours_8th_edition_24\%20Jan\%202018.pptx\#: :text=The\%20UICC\%2 0TNM\%20Project\%20has\%20published\%20the\%208th,TNM\%20classification $\% 20$ be $\% 20$ always $\% 20$ included $\% 20$ in $\% 20$ data $\% 20$ rep orting [Last accessed on 20 May 2021].

12. Iida T, Nomori H, Shiba M, et al. Prognostic factors after pulmonary metastasectomy for colorectal cancer and rationale for determining surgical indications: a retrospective analysis. Ann Surg 2013;257:1059-64. DOI PubMed

13. Shimada H, Kitabayashi H, Nabeya Y, et al. Treatment response and prognosis of patients after recurrence of esophageal cancer. Surgery 2003;133:24-31. DOI PubMed

14. Kunisaki C, Makino H, Takagawa R, et al. Surgical outcomes in esophageal cancer patients with tumor recurrence after curative esophagectomy. J Gastrointest Surg 2008;12:802-10. DOI PubMed

15. Depypere L, Lerut T, Moons J, et al. Isolated local recurrence or solitary solid organ metastasis after esophagectomy for cancer is not the end of the road. Dis Esophagus 2017;30:1-8. DOI PubMed

16. Hiyoshi Y, Morita M, Kawano H, et al. Clinical significance of surgical resection for the recurrence of esophageal cancer after radical esophagectomy. Ann Surg Oncol 2015;22:240-6. DOI PubMed

17. Shiono S, Kawamura M, Sato T, et al. Disease-free interval length correlates to prognosis of patients who underwent metastasectomy for esophageal lung metastases. J Thorac Oncol 2008;3:1046-9. DOI PubMed

18. Chen F, Sato K, Sakai H, et al. Pulmonary resection for metastasis from esophageal carcinoma. Interact Cardiovasc Thorac Surg 2008;7:809-12. DOI PubMed

19. Takemura M, Sakurai K, Takii M, Yoshida K. Metachronous pulmonary metastasis after radical esophagectomy for esophageal cancer: prognosis and outcome. J Cardiothorac Surg 2012;7:103. DOI PubMed PMC

20. Ichikawa H, Kosugi S, Nakagawa S, et al. Operative treatment for metachronous pulmonary metastasis from esophageal carcinoma. Surgery 2011;149:164-70. DOI PubMed

21. Ichida H, Imamura H, Yoshimoto J, et al. Pattern of postoperative recurrence and hepatic and/or pulmonary resection for liver and/or lung metastases from esophageal carcinoma. World J Surg 2013;37:398-407. DOI PubMed

22. Kobayashi N, Kohno T, Haruta S, et al. Pulmonary metastasectomy secondary to esophageal carcinoma: long-term survival and prognostic factors. Ann Surg Oncol 2014;21 Suppl 3:S365-9. DOI PubMed

23. Kozu Y, Oh S, Takamochi K, Suzuki K. Surgical outcomes of pulmonary metastases from esophageal carcinoma diagnosed by both pathological and clinical criteria. Surg Today 2015;45:1127-33. DOI PubMed

24. Kanamori J, Aokage K, Hishida T, et al. The role of pulmonary resection in tumors metastatic from esophageal carcinoma. Jpn J Clin Oncol 2017;47:25-31. DOI PubMed

25. Kato F, Monma S, Koyanagi K, et al. Long-term outcome after resection for recurrent oesophageal cancer. J Thorac Dis 2018;10:2691-9. DOI PubMed PMC

26. Shimada A, Tsushima T, Tsubosa Y, et al. Validity of Surgical Resection for Lymph Node or Pulmonary Recurrence of Esophageal Cancer After Definitive Treatment. World J Surg 2019;43:1286-93. DOI PubMed 